NBER WORKING PAPER SERIES

\title{
LABOR FORCE ENTRY AND EXIT OF OLDER MEN: \\ A LONGITUDINAL STUDY
}

Frederic P. Slade

Working Paper No. 1029

\section{NATIONAL BUREAU OF ECONOMIC RESEARCH 1050 Massachusetts Avenue Cambridge MA 02138}

\author{
November 1982
}

The research reported here is part of the NBER's research program in Health Economics. Any opinions expressed are those of the author and not those of the National Bureau of Economic Research. 
Labor Force Entry and Exit of Older Men:

A Longitudinal Study

\section{ABSTRACT}

The labor force participation rate of older men under age 65 has shown a significant recent decline. Cross-sectional studies linking early retirement to increased Social Security income have also made explicit or implicit temporal projections of changes in participation in response to changes in benefits. However, use of cross-sectional estimates for projection purposes may run into several problems, including temporal dependence of the participation decision. This paper uses 2-year longitudinal data for men aged 58-62 in 1969 in order to trace changes in labor force behavior near retirement age. Results indicate significant effects of poor health, initial assets, and initial pension eligibility on the probabilities of exit and entry from the labor force. Social Security benefits a re found to have insignificant or unexpected effects. The results also indicate evidence of temporal dependence of particlpation, suggesting caution in interpreting projections of cross-section estimates.

Frederic P. Slade

Rutgers University Department of Economics Hill Hall - 8th Floor Newa rk, N.J. 08817

(201) 648-5259 
I. Int roduction

There has been a significant recent decrease in the labor force par ticlpation rates of older men under age 65 . In the 55-64 age group the participation rate was 75.8 per cent 1 n 1975 as opposed to 86.8 per cent in 1960. On the other hand, there has been rapid concurrent growth in two major sources of early retirement income -- Social Security and non-Social Security pensions. The two major sources of Social Security growth have been Disability Insurance (DI) benefit payments, which increased in real terms from $\$ .8$ billion in 1960 to $\$ 6.7$ billion in 1975, and 01d Age (OA) benefits, which increased in real terms from $\$ 11.4$ billion to $\$ 34.1$ billion over the same period. In addition non-Social Security pension benefits increased in real terms from $\$ 6.3$ billion to $\$ 25.9$ billion.

Most previous survey research dealing with self-reported causes for retirement had found poor health to be dominant. 1 For example, Schwab (1974) found that 65 per cent of men aged 58-63 who left the labor force in 1969 mentioned health as the reason for withdrawal. However, recent research regarding actual work decisions have found economic variables such as Soctal Securtty or other pension benefits to be important determinants of retirement among the elderly.

Most studies of the effect of Social Security and pensions on labor force participation have focused on the effect of the 01d-Age system and pensions on retirement, ${ }^{2}$ while other studies have examined the effect

For an exhaustive list of references, see Boskin (1977). Selfreported responses may be misleading since it may be socially acceptable to state poor health as a reason for retirement.

${ }^{2}$ See Bowen and Finegan (1969), Feldsteln (1974), Boskin (1977), Quinn (1977), Pellechio (1978) 
of Disabllity Insurance on labor force particlpatlon. ${ }^{3}$ These studles have primarily utilized cross-section data, and almost all have found Social Security and pensions to have significant negative effects on participation. Many of these studies have then used these estimates to predict the effect of (temporal) changes in Social Security benefits and tax rates on the participation probability. 4,5

However, use of cross-section estimates to predict time-oriented behavior may have several drawbacks. First, the variables in a cross section represent equilibrium values, and therefore lags in the individual par ticipation decision a re not allowed for as would be the case with longitudinal or panel data.

Secondly, cross-section estimates do not capture the effect of structural changes over time in Social Security and other pension programs on Individual behavior.

Thirdly, in looking at an individual's sequential participation decision, there may be dependence among the decisions at different points in time. That is, an Individual may be more likely to work (not work) in period $t$ if they worked (didn't work) in period $t-1$. This problem of temporal dependence is discussed in more detail in the next section. If temporal dependence is present, cross-section data may be inadequate

${ }^{3}$ See Berkowitz, et al (1976), Parsons (1980a,b). Most of these studies use samples of middle aged men or men aged 18-64.

${ }^{4}$ Parsons (1980a) used cross-section estimates to predict trends in nonparticlpation from 1948-1966 for males aged 48-62. Other predictions have been implicitly temporal, since changes in Social Security parameters are legislated over time.

5he primary tax rate examined has been the so-called "earnings test," whereby there is an implicit tax consisting of a 50-cent reduction in retirement benefits for every dollar earned above an exempt amount. 
in predicting the sequential participation probability of an individual as well as the participation rate of a given age group of individuals.

In order to attempt to address and examine these problems, this paper uses a longitudinal sample of older men ext racted from the Longitudinal Retirement study (LRHS). Although these men a re traced over only a twoyear period, the effect of changes in Social Security benefits, pension coverage, and other variables on labor force entry and exit at or near retirement age can be examined.

Section II examines more closely the issue of temporal dependence, while Section III presents the empirical implementation and results.

\section{Temporal Dependence of Labor Force Participation}

The problem of temporal dependence of the labor force participation - decision has been discussed by authors such as Heckman and Willis (1977), Ben-Porath (1973), Long and Jones (1980), and Taubman and Rosen (1982).

An example of temporal dependence is shown in Figure 1.

\section{Figure 1}

Temporal Dependence of the Labor Force Participation Decision

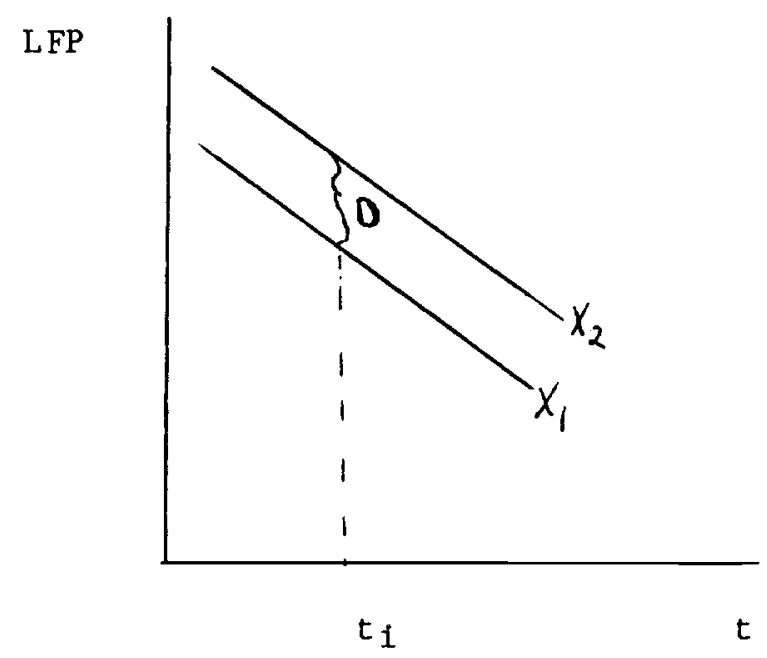


The two parallel lines show the relationship between labor force participation (LFP) and time ( $t$ ), for two values of the independent vartable $\left(X_{1}\right.$ and $\left.X_{2}\right)$. A cross-section estimate of $X$ would measure the distance $D$ between the two lines for some point in time $\left(t_{i}\right)$. A regression using longitudinal data would be measuring the effect of a change in $X$ on the change in participation over time, $\frac{d L F P}{d t}$ In Figure 1, we would then be comparing the slopes of the two lines for different values of $x$. Since the lines are parallel, $\frac{d L F P}{d t}$ would be the same for both $X$ because of temporal dependence in the participation decision. Therefore, the cross-section estimate could not be used to predict individual labor force participation over time.

Several sources of temporal dependence have been noted in the literature, two of which are discussed here. $6^{\circ}$ The first source is known as "true" dependence (Heckman and Willis (1976), Ben-Porath (1973)). This occurs if there are transactions costs of working. This would include fixed costs of working, employee search costs, costs of not working, or employer hiring costs. For example, if there are fixed costs of working and the individual is out of the labor force, the condition that the wage exceed the shadow price of time may not be sufficient to induce participation,

6 One source of dependence not discussed here is known as "apparent" state dependence (Heckman and Willis, 1977). This is caused by permanent unobserved differences among observationally identical individuals which may persist over time. Heckman and Willis show that cross-section estimates may be used to predict the sequential participation behavior of an average individual within a group; however, this estimate will differ from the average behavior of the group itself. 
since a gap is induced between the shadow price of time ind the reservation wage. ${ }^{7}$ An example of costs of not working is found with the Disability Insurance (DI) program. The DI prograin requires an applicant for benefits to have been disabled for at least five months (six months prior to 1972) before they can receive benefits. This time cost of this "waiting period" (in addition to any delays in the processing of the application) will be valued at the individual's pre-application earnings. As a result, an increase in DI benefits for a worke $r$ may cause the shadow price of time to rise above the market wage; however, application costs may prevent the individual from dropping out of the labor force and applying for benefits. 8

A second major source of temporal dependence are variables which are time-varying. Examples of this a re changes in residence, changes in health, or changes in non-labor income (such as Social Security benefits). For example, we might expect an initial deterioration in health to strongly affect the sequential participation probability of an individual, but would expect the effect of any subsequent worsening to "die off" over time.

As a result of these two sources of temporal dependence, we may be unable to predict individual sequential participation behavior using

7 The concept of fixed costs of working is discussed by Cogan (1981) and Hausman (1980).

${ }^{8}$ Although there is no direct evidence linking the dectsion to apply for DI benefits and the decision not to work, the presence of the aforementioned "waiting period," as well as the decision to apply as a result of a past or present disability, point to equivalence of the two decisions. This equivalence is assumed by authors such as Parsons (1980a,b) 
cross-sectlonal estlmates. Therefore, longltull mal datin is nooded to

trace changes in labor force partlclpation and tme-varylng tndependent varlables.

II. Data and Empirlcal Implementation

We will attempt here to examine the effect of Social Security and other variables on changes in labor force participation over time, as well as to test for the presence of temporal dependence in the participation decision. The empirical framework involves the estimation of separate equations measurting the probability of exit from and entry into the labor force.

The micro data used for estimation a re taken from the 1969 original sample and the 1971 reinterview sample of the Longttudinal Retirement History Study (LRHS). The final sample extracted consisted of 2991 males aged 58-62 in 1969 who were Insured by the Social Security system based on their past earnings and employment. ${ }^{9}, 10$

The labor force behavior of these men was determined for 1968 and 1970 , the year previous to each interview. This was to minimize the effect of transitory factors on labor force behavior. The labor force activity for these men between 1968 and 1970 was given by the following totals (where $N L F=$ not in labor force):

${ }^{9}$ In order to be insured for both DI and retirement (OASI) benefits, the individual must have had at least 20 quarters of coverage during the 40-quarter period ending with the quarter in which a disability may have begun (Disability Insured status). This is in addition to having the sufficient quarters of coverage for OASI benefits.

10 The original 1969 LRHS sample was aged 58-63. However, we eliminated those aged 63 in 1969 (age 65 in 1971) in order to distinguish between disability benefits and early retirement benefits. At age 65 , disability benefits become regular retirement benefits under Social Security. 
Number of: Men

261

56

2192

Total: $\quad \frac{482}{2991}$ $\frac{\text { Labor Force Behtavior During }}{1968}$

NLF

NLF

WORK ING

WORK ING
NLF

WORK ING

WORK ING

NLF

Using the above classifications, the dependent variable representing entry into the labor force is defined as:

ENTRY. $=\left\{\begin{array}{l}0 \text { if NLF in } 1968 \text { and NLF in } 1970 \\ 1 \text { if NLF in } 1968 \text { and WORK ING in } 1970\end{array}\right.$

The variable representing exit from the labor force is defined as:

EXIT $=\left\{\begin{array}{l}0 \text { if WORK ING in } 1968 \text { and WORK ING in } 1970 \\ 1 \text { if WORKING in } 1968 \text { and NLF in } 1970\end{array}\right.$

Table 1 defines the independent variables to be used in the EXIT and ENTRY equations. Because of the timing of the LRHS survey, certain variables such as marital status, assets, and age we re based on current responses given at the time of the surveys in 1969 and 1971 . We will assume here that these variables also pertain to the previous year (1968 and 1970).

Variables measuring the individual's assets (ASSETS and $\triangle$ ASSETS) include the value of stocks, bonds, savings accounts, and life insurance, as well as the net value of property or business. Increases in asset income would be expected to increase the exit probability through the income effect, if liesure is a normal good. In addition, if the individual chooses to exit the labor force in order to apply for DI benefits, an increase in assets would better enable the individual to "finance" the application costs involved (waiting period, delays in processing) 
Table 1

Definitions of Independent Variables Used in EXIT and FNTRY Equations

\begin{tabular}{|c|c|}
\hline ED & $=$ years of schooling completed \\
\hline AGE & $=$ age, in 1969 interview \\
\hline ASSETS & $=$ dollar value of assets in 1969 (in thousands) \\
\hline$\triangle A S S E T S$ & $\begin{array}{l}=\text { dollar value of assets in } 1971 \text { minus dollar value of assets } \\
\text { in } 1969 \text { (in thousands) }\end{array}$ \\
\hline WAGE & $=$ hourly wage rate in 1968 \\
\hline$\triangle W A G E$ & $=$ hourly wage rate in 1970 minus hourly wage rate in 1968 \\
\hline DIBEN & $\begin{array}{l}=\text { potential monthly benefits from Social Security Disability } \\
\text { Insurance (DI) in } 1968\end{array}$ \\
\hline$\triangle D I B E N$ & $\begin{array}{l}=\text { potential DI monthly benefits in } 1970 \text { minus potential DI } \\
\text { monthly benefits in } 1968\end{array}$ \\
\hline REDBEN & $=$ potential monthly reduced retirement (OA) benefits in 1968 \\
\hline$\triangle \mathrm{REDBEN}$ & $\begin{array}{l}=\text { potential reduced OA monthly benefits in } 1970 \text { minus potential } \\
\text { reduced OA monthly benefits in } 1968\end{array}$ \\
\hline ELIG & $\begin{array}{l}=\text { dummy variable equal to l if currently eligible for benefits } \\
\text { from a pension plan (other than Social Security or Railroad } \\
\text { Retirement) in } 1969 \text {, O otherwise }\end{array}$ \\
\hline RACE & $=$ dummy va riabie equal to 1 if black, 0 otherwise \\
\hline LIMIT & $\begin{array}{l}=\text { dummy va riable equal to } 1 \text { if had a health condition or } \\
\text { disability which limited getting a round in } 1969 \text {, otherwise }\end{array}$ \\
\hline GOTLIM & $\begin{array}{l}=\text { dummy variable equal to } 1 \text { if developed a health condition or } \\
\text { disability between the two interview dates, } 0 \text { otherwise }\end{array}$ \\
\hline MOVE & $\begin{array}{l}=\text { dummy variable equal to } 1 \text { if changed address between interview } \\
\text { dates, } 0 \text { otherwise }\end{array}$ \\
\hline MAR IT & $\begin{array}{l}=\text { dummy variable equal to l if married as of } 1969 \text { interview, } \\
0 \text { otherwise }\end{array}$ \\
\hline
\end{tabular}


The variables WAGE and $\triangle$ WAGE measure the Individual's Inttial hourly wage rate and change from 1968 to 1970 . There may be sample selectivity bias if usual missing data procedures are used for assigning wages to nonparticipants (such as the sample mean). This is because the relationship between selection into the working sample (participation) and the availabi1ity of wage data is ignored (see Hausman (1980), Heckman (1976)). In order to correct for possible selectivity bias, wages were imputed for nonworkers in 1968 and 1970. The imputed wages were based on the following log-wage regression estimated on the 1968 working subsample:

$$
\begin{aligned}
& \text { LNWAGE }=\underset{(-.6)}{-.391}+\underset{(11.4)}{.055 \mathrm{ED}}+\underset{(1.0)}{.013 \mathrm{AGE}}-\underset{(-.16)}{.010 \mathrm{RACE}} \\
& -.052 \text { LIMIT }+.082 \text { MARIT }-.654 \text { LAMDA } \mathrm{R}^{2}=.04
\end{aligned}
$$

where LAMDA is the selectivity correction factor (inverse of Mill's ratio). 11

The variables $D I B E N$ and $\triangle D I B E N$ measure the individual's potential monthly benefits under Social Security Disability Insurance. Calculations were based on the 1968 and 1970 benefit formulas, using past covered earnings from the individual's Social Security employment record (this record had been merged with their LRHS data). The calculated benefits were then deflated using implicit price deflators for consumer expenditures. Note that since potential (as opposed to actual) benefits are used, there is no simultaneity problem in the sense of benefits depending upon labor force participation.

${ }^{11}$ The imputed wages for nonworkers were based on the particular values of the independent va riables in equation (1) for the year in question. Unfortunately, comparable information on place of residence was not available in the 1969 and 1971 surveys; this omission may partly explain the low $R$-squared value of the wage equation. 
The variables REIDBEN and $\triangle$ REIBBEN measure potent lal Soclal Securtty reduced rettrement benefts for 1968 and 1970, agaln calculated from the individual's Social Security record. These benefits were also deflated. For individuals aged 62-64, reduced retirement benefits represent an alternative early retirement source to Disability Insurance. 12

The variable MOVE is a dummy indicating a change in address during the 2-year interval. This variable may in part reflect changing labor market conditions. However, for this sample of older men, MOVE may la rgely reflect movement to a warmer climate suitable for retirement years. Distinguishing between the two possibilities is an empirical question.

The variable ELIG is a dummy indicating current eligibility in 1969 for benefits from a non Social Security (private and public) penston plan. The - eligible individual is entitled to a stream of pension benefits from date of retirement until his death. We would therefore expect the individual to retire in order to maximize his expected benefit stream (see Taubman (1981)).13

The variables LIMIT and GOTLIM a re dummy variables indicating presence of a self-reported health limitation in 1969 and development of a limitation

$12_{\mathrm{At}}$ age 65 , Disability Insurance benefits revert to old-age retirement benefits under Social Security. Even though DI benefits exceed reduced retirement benefits at a given age (since there is no reduction for DI), persons may still choose to apply for reduced retirement benefits for such reasons as "stigma" attached to receiving DI.

13 There is evidence that ELIG may be endogenous. Taubman (1981) found expected receipt of a pension to be significantly related to education, marital status, occupation, industry, and assets. However, because ELIo does refer to job related pensions (and because of statistical complications resulting from self-selection into pension plans) we treat FLIG as exogenous.

The analysis also suggests including a dummy variable for having become eligible for a pension between 1968 and 1970. However, this variable was not included since length of service requirements for pension eligibility would make this virtually identical to having worked in both 1968 and 1970 . 


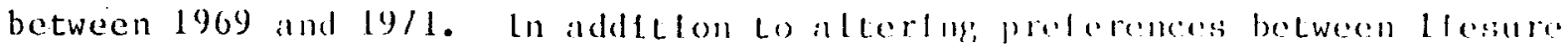
and consumption goods, the development of a disablltty will of course increase the probability of being accepted for DI benefits. This would then increase the probabillty of dropping out of the labor force in orcler to apply for benefits.

RACE is a dummy variable denoting the individual's race, and allows us to test for black-white differences in labor force attachment among older men. MARIT is a dummy variable representing ma rital status.

ED and AGE indicate the individual's years of schooling completed and age in 1969, respectively. These variables might be expected to affect entry and exit by altering the individual's preference between liesure and consumption goods over the life cycle, through their effect on personal tasţes or home productivity (see Becker (1965), Hanoch (1976), Grossman (1972)). For example, if schooling has the effect over time of raising the cost of time producing household commodities (relative to the cost of market good inputs), we would expect schooling to be negatively related to the probability of exit from the labor force.

In addition to more closely examining changes in participation, separate estimation of entry and exit equations allow is to test for the extent of temporal dependence in individual participation decisions.

If there is no temporal dependence, then relationships normally found in cross section relationships can be applied to longitudinal relationships. For example, if an increase in assets decreases the probability of working in a cross-section, then an increase in assets between 1968 and 1970 would increase the probability of exiting the labor force over this interval. Symmetrically, a decrease in assets between 1968 and 1970 would increase the probability of entering the labor force. If the relationships 
a re not symmetrleal and/or tastgnLflcant, there is Indtcat ton of temporil dependence.

Additional evidence of temporal dependence is revealed by the effect of "Initial variables" (e.g. WAGE, DIBEN, ASSETS) on the probability of ent ry and exit from the labor force. Initial variables will affect cumulative labor force participation over time. However, only if there is temporal dependence would we also expect these variables to affect changes in the participation probability (probability of entry and exit). For example, an initial increase in the wage rate may reduce the exit probability, possibly because of fixed costs of reentering the labor forçe if the individual stops working. Therefore, significance of these initial variables in the EXIT or ENTRY equations would imply tempora1 dependence.

Table 2 shows preliminary maximum likelihood probit estimates of the ENTRY and EXIT equations. Column (1) of each equation used the full sample of 2991 men. Column (2) used a subsample of 2273 men in order to construct the variable GOTLIM, which included men who either had no self-reported health limitation in the two interview dates, or developed a limitation between the two dates. Although columns (1) and (2) of the ENTRY and EXIT equations differed somewhat in the magnitude of the coefficient estimates, the significance levels of the standard errors were largely unchanged.

The individuals' initial level of assets (ASSETS) had a significant positive effect on the exit probability and a significant negative effect on the entry probability. However, changes in asset income (DASSETS) had significant effects in both equations.

The race dummy variable ( $R A C E$ ) had negative coefficients in both the ENTRY and EXIT equations, though the coefficient was significant in the EXIT equation only. This suggests a greater labor force attachment for 


\section{Table 2}

Maximum t.tkelthood Problt fstimites of liNTRY and lixi'r equations, Males Aged 58-63

\begin{tabular}{|c|c|c|c|c|c|c|c|c|}
\hline \multirow{2}{*}{$\begin{array}{c}\text { Independent } \\
\text { Variable }\end{array}$} & \multicolumn{2}{|c|}{$\begin{array}{c}\text { Maximum Likelihood } \\
\text { Coefficient }\end{array}$} & \multicolumn{2}{|c|}{$\frac{\partial L F P}{\partial X}$} & \multicolumn{2}{|c|}{$\begin{array}{c}\text { Maximum Likelihood } \\
\text { Coefficient } \\
\end{array}$} & \multicolumn{2}{|c|}{$\frac{\partial L F P}{\partial X}$} \\
\hline & $(1)$ & (2) & (1) & (2) & (1) & (2) & (1) & $\overline{(2)}$ \\
\hline ED & .0617 & .0202 & & & .0122 & .1318 & & \\
\hline AGE & .0483 & $\begin{array}{c}(.5) \\
.0377\end{array}$ & .0153 & .0046 & $\begin{array}{r}(.2) \\
-.1570\end{array}$ & $\begin{array}{r}(1.0) \\
-.1618\end{array}$ & .0023 & .0360 \\
\hline & $(.8)$ & $(.6)$ & .0119 & .0086 & $(-.8)$ & $(-.6)$ & -.0294 & -.0442 \\
\hline ASSETS & .0019 & .0021 & & & -.0076 & -.0073 & & \\
\hline 1 & $(4.7) * *$ & $(4.5) * *$ & .0005 & .0005 & $(-2.2) *$ & $(-2,1) *$ & -.0014 & -.0021 \\
\hline$\triangle \mathrm{ASSETS}$ & $\begin{array}{l}.0010 \\
(1.8)\end{array}$ & $\begin{array}{l}.0010 \\
(1.4)\end{array}$ & .0002 & .0002 & $\begin{array}{l}-.0001 \\
.(-.1)\end{array}$ & $\begin{array}{r}.0002 \\
(.1)\end{array}$ & -.0001 & .0001 \\
\hline WAGE & $\begin{array}{r}-.2647 \\
(1.4)\end{array}$ & $\begin{array}{r}.1548 \\
(.5)\end{array}$ & -.0655 & .0354 & $\begin{array}{r}-1.2851 \\
(-1.6)\end{array}$ & $\begin{array}{r}-1.8792 \\
(-1.5)\end{array}$ & -.2410 & -.5136 \\
\hline$\triangle$ WAGE & $\begin{array}{r}-.2727 \\
(-1.5)\end{array}$ & $\begin{array}{r}.1513 \\
(.4)\end{array}$ & -.0675 & .4428 & $\begin{array}{r}.3616 \\
(.5)\end{array}$ & $\begin{array}{r}-3.4344 \\
(-1.8)\end{array}$ & .0678 & -.9386 \\
\hline RACE & $\begin{array}{l}-.3134 \\
(-2.8) * *\end{array}$ & $\begin{array}{r}-.2053 \\
(-1.6)\end{array}$ & -.0776 & -.0469 & $\begin{array}{r}-.4849 \\
(-1.5)\end{array}$ & $\begin{array}{r}-.1581 \\
(-.4)\end{array}$ & -.0909 & -.0432 \\
\hline DIBEN & $\begin{array}{r}-.0011 \\
(-.8)\end{array}$ & $\begin{array}{r}-.0012 \\
(-.8)\end{array}$ & -.0003 & -.0003 & $\begin{array}{r}-.0048 \\
(-1.1)\end{array}$ & $\begin{array}{r}-.0058 \\
(-.9)\end{array}$ & -.0009 & -.0016 \\
\hline$\triangle D I B E N$ & $\begin{array}{l}-.0423 \\
(-6.8) * *\end{array}$ & $\begin{array}{l}-.0324 \\
(-4.4) * *\end{array}$ & -.0105 & -.0074 & $\begin{array}{r}.0832 \\
(4.5)\end{array}$ & $\begin{array}{l}.0726 \\
(3.1) * *\end{array}$ & .0156 & .0199 \\
\hline REDBEN & $\begin{array}{r}.0001 \\
(.1)\end{array}$ & $\begin{array}{r}.0001 \\
(.1)\end{array}$ & .0001 & .0001 & $\begin{array}{r}.0051 \\
(1.2)\end{array}$ & $\begin{array}{r}.0039 \\
(.7)\end{array}$ & .0010 & .0011 \\
\hline$\triangle$ REDBEN & $\begin{array}{r}.0001 \\
(.1)\end{array}$ & $\begin{array}{r}.0001 \\
(.1)\end{array}$ & .0001 & .0001 & $\begin{array}{r}.0027 \\
(1.1)\end{array}$ & $\begin{array}{r}.0025 \\
(.7)\end{array}$ & .0005 & .0007 \\
\hline LIMIT & $\begin{array}{l}.2715 \\
(3.7) * *\end{array}$ & & .0672 & & $\begin{array}{l}-.7974 \\
(-3.0) * *\end{array}$ & & -.1495 & \\
\hline GOTLIM & & $\begin{array}{r}.1951 \\
(1.4)\end{array}$ & & .0446 & & $\begin{array}{l}-1.3550 \\
(-2.1) *\end{array}$ & & -.3703 \\
\hline ELIG & $\begin{array}{l}.3318 \\
(3.4) * *\end{array}$ & $\begin{array}{l}.1854 \\
(2.1) *\end{array}$ & .0821 & .0424 & $\begin{array}{l}-.8391 \\
(-3.0) * *\end{array}$ & $\begin{array}{r}-.6400 \\
(-2.0) *\end{array}$ & -.1573 & -.1749 \\
\hline MARIT & $\begin{array}{r}.0442 \\
(.4)\end{array}$ & $\begin{array}{r}-.7345 \\
(-.6)\end{array}$ & .0109 & -.0168 & $\begin{array}{r}-.0304 \\
(-.1)\end{array}$ & $\begin{array}{r}.5958 \\
(1.1)\end{array}$ & -.0057 & .1628 \\
\hline MOVE & $\begin{array}{l}.2840 \\
(3.5) * *\end{array}$ & $\begin{array}{l}.3220 \\
(3.4) * *\end{array}$ & .0703 & .0736 & $\begin{array}{r}.0198 \\
(.1)\end{array}$ & $\begin{array}{r}-.2564 \\
(-.8)\end{array}$ & .0037 & -.0701 \\
\hline CONSTANT & -3.2786 & -3.2433 & & & 11.2221 & 12.1029 & & \\
\hline $\begin{array}{l}-2 \text { times } \log \\
\text { 1tkelihood ratio } \\
\mathrm{N}\end{array}$ & $\begin{array}{r}190.4 \\
2674\end{array}$ & $\begin{array}{l}97.7 \\
2118\end{array}$ & & & $\begin{array}{r}73.5 \\
317\end{array}$ & $\begin{array}{r}40.1 \\
155\end{array}$ & & \\
\hline
\end{tabular}


older black inen; however, the negative effect of RACE in the RNTRY equat Lon suggests caution in interpreting the results.

The presence of a self-reported limiting health condtion in the initial year (LIMIT) had significant coefficients in both equations, indicating a positive effect of initial poor health on the probability of labor force exit, and a negative effect on the probability of entry. Development of a limiting health condition (GOTLIM) had the expected signs, although its coefficient was significant only in the ENTRY equation. Change in address (MOVE) had a positive and significant effect in the EXI'T equation, but an insignificant effect in the ENTRY equation. " The results suggest that this variable is measuring movement to a warmer climate for retirement purposes, as opposed to a labor market response.

Present eligibility for non-Social Security pension benefits in 1969 (ELIG) was highly significant in both ENTRY and EXIT equations. Pension eligibility was positively related to the exit probability and negatively related to the entry probability. Though expected, this result also indicates a somewhat delayed retirement response to current pension eligibiIity.

Looking at the Social Security variable, potential reduced retirenent benefits (REDBEN and $\triangle$ REDBEN) were insignificant in both the ENTRY and EXIT equations. Initial potential Disability Insurance benefits (DIBEN) also had insignificant effects. Change in DI benefits ( $\triangle D I B E N$ ) had significant coefficients in both equations, but the signs were opposite to the expected ones (negative for EXIT and positive for ENTRY). One possible explanation for this is that DI benefits are a positive function of past covered wages. Therefore, $\triangle D I B E N$ may have been picking up a permanent wage effect as opposed to the intended income effect, whereas WAGE and $\triangle$ WAGE may have actually been measures of transitory wages. 
The other variables In Table 2 were Instgniflcant. Schooling, (ED) was positfve and stgniflcant in column ( 1 ) of the EXIT equation but insignificant elsewhere.

The empirtcal results also indicated a high degree of temporal dependence in the labor force participation decision. Partlal evidence of this was the significance of "initial" variables (ASSETS, LIMIT, ELIG) in the exit and entry equations. Additional evidence was found in the insignificance of "change" varlables ( $\triangle$ ASSETS, $\triangle$ WAGE, $\triangle$ REDBEN) which would have been expected (in the absence of temporal dependence) to have significant effects based on previous cross-section results. This implies the need for caution in interpreting projections of temporal changes in participation based on cross-section estimates, a1though the disappointing results here for the Social Security variables do not allow us to make meaningful alter native projections.

Conclusion

This paper has examined determinants of the declining labor force par ticipation rates of older men under age 65 . Previous attempts to use cross-sectional estimates to predict temporal effects of changes in Social Security and other variables on retirement may have several potential problems including temporal dependence of labor force participation therefore suggesting use of longitudinal data.

The empirical implementation involved separate estimation of equations measuring the probability of exit from and entry into the labor force over a 2-year period. The sample used consisted of men aged 58-62 in 1969 extracted from the 1.969 and 1971 waves of the Longitudinal Retirement History Study (LRHS). Among noneconomic vartables, maximum likelihood probit estimates indicated significant effects of poor health (both inftial and acquired) on the probabilities of entry and exit. Among the economic 
variables, inttal eligibiltty for non-Soctal security penston benefits and Inttal asset income had slgulftcant negative (posttlve) effects on the entry (exit) probabilities. Social Security (retirement and DI) benefits had efther insignfficant or unexpected effects. Overall, the results indicated temporal dependence in the participation decision, suggesting caution in interpreting projections of cross-section estimates.

The result obtalned here pertaln to a falrly short time horizon. Examination of retirement over a longer period would, first, allow the effects of short-term changes in Soclal Security benefits (as well as "initial" changes) to be examined in a life-cycle retirement framework, and secondly, would more fully allow for response lags in the retirement decision. Analysis of further LRHS reinterview waves from 1973 through 1979 w11l be of use in this matter. 
References

1. Amertcnn Councll of Life Insurance, Penston Facts, 1977

2. Becker, G. "A Theory of the Nllocation of Time," Economic Journa1, September 1965

3. Ben-Porath, Y. "Labor Force Participation Rates and the Supply of Labor," Journal of Political Economy, May/June 1973

4. Be rkowitz, M., W.G. Johnson, and E.H. Murphy, Public Policy Toward Disability, New York: Praeger, 1976

5. Boskin, M. "Social Security and Retirement Decisions," Economic Inquiry, January 1977

6. Bowen, W. and T. Finegan. The Economics of Labor Force Participation, Princeton: Princeton University Press, 1969

7. Cogan, J. "Fixed Costs and Labor Supply," Econometrica, July 1981

8. Feldstein, M. "Social Security and Private Capital Accumulation: International Evidence in An Extended Life-Cycle Model," Ha rvard Institute of Economic Research Discussion Paper, 1974

9. Grossman, M. "The Demand for Health: A Theoretical and Empirical Investigation," Occasional Paper 119, NBER, 1972

10. Hanoch, G. "A Multivariate Model of Labor Supply: Methodology for Estimation," Rand Corporation, 1976

11. Hausman, J. "The Effect of Wages, Taxes and Fixed Costs on Women's Labor Force Participation," Journal of Public Economics, 14 (1980)

12. Heckman, J. "The Common Structure of Statistical Models of Truncation, Sample Selection, and Limited Dependent Variables and a Simple Estimator for Such Models," Annals of Economic and Social Measurement, Fall 1976

13. and R.J. Willis. "A Beta-Logistic Model for the Analysis of Sequential Labor Force Participation by Married Women," Journal of Political Economy, Vol. 85, no. 1 (1977)

14. Kalachek, E., W. Mellow, and F. Raines. "The Male Labor Supply Function Reconsidered," Industrial and Labor Relations Review, 31, Apri1 1978 
15. Long, J. and F. Jones, "Labor Force Entry and Exit by Married Women:

A Longitudinal Analysis," Review of Fconomics and

Statistics, February 1980

16. Parsons, D. "The Decline in Male Labor Force Participation," American Economic Review, February, 1980(a)

17. - "Racial Trends in Male Labor Force Participation," Ame rican Economic Review, December, 1980(b)

18. Pellechio, A. "The Effect of Social Security on Retirement," Workinig Paper No. 260, NBER, July 1978

19. Quinn, J. "Microecononic Determinants of Early Retirement: A CrossSectional View of White Married Men," Journal of Human Resources, Summer, 1977.

20. Schwab, K. "Early Labor Force Withdrawa 1: Participants and NonParticipants Aged 58-63," Social Security Bulletin, August 1974

21. Taubman, P. "Pensions and Mortality," Working Paper No. 811, NBER, December 1981

22. and S. Rosen, "Healthiness, Education, and Marital Status," in V. Fuchs (ed), Economic Aspects of Health, Chicago: University of Chicago Press, 1982

23. U.S. Social Security Administration, Social Security Handbook, Washington, D.C.: U.S. Governinent Printing Office, 1978

24. History of the Provisions of Old-Age, Survivors, Disability, and Health Insurance, 1980

25. Soclal Security Bulletin: Annual Statistical Supplement, $\underline{1980}$ 